Revista de Psicología Vol. 39 (2), 2021 (e-ISSN 2223-3733)

\title{
Obedience to authority, cognitive and affective responses and leadership style in relation to a non-normative order: the Milgram experiment
}

\author{
Silvia da Costa $^{1 *}$, Gisela Delfino ${ }^{2}$, Marcela Murattori ${ }^{3}$, Elena Zubieta ${ }^{4}$, Lucía \\ García $^{5}$, Dario Páez ${ }^{6}$, Maite Beramendi ${ }^{7} \&$ Fernanda Sosa ${ }^{8}$ \\ University of the Basque Country-Spain; Catholic University of Buenos Aires, \\ Argentina; University of Buenos Aires, Argentina; London School of Economics, \\ UK; National University of the Argentine Defense
}

The influence of the context on behavioral and emotional reactions to a war crime situation military cadets $(N=315)$ is analyzed. The study is based on Milgram's experience and the tragedy of My Lai.It examines personal and peer obedience to an anti-normative order (asking participants whether they would obey an order to shoot unarmed civilians) in five vignettes or scenarios that reproduce Milgram's conditions and MyLai scenario. This

$1 \quad \mathrm{PhD}$. by University of the Basque Country. Professor and Researcher at University of the Basque Country. Postal Address: Zuberoa 8, 3B, 20800, Zarautz, Gipuzkoa, España. Contact: pmsded2021@gmail.com. https://orcid.org/0000-0001-6011-821X

2 PhD. by Catholic University of Buenos Aires. Professor and Researcher at Pontifical Catholic University of Argentina. Postal Address: Alicia Moreau de Justo $16002^{\circ}$, CP 1107, Ciudad de Buenos Aires. Contact: gisela_delfino@uca.edu.ar. https://orcid. org/0000-0002-3732-184X

3 PhD. by Catholic University of Argentina. Professor and Researcher at National University of the Argentine Defense. Postal Address: Avenida Santa Fe 1771- 4C. Martínez. Buenos Aires, Argentina. (CP 1640). Contact: marcelamuratori@hotmail.com.

4 PhD. By University of the Basque Country. Professor at University of Buenos Aires. Postal Address: Tucumán 2162, $8^{\circ}$ A (1050) Ciudad Autónoma de Buenos Aires. Contact: elenazubieta@hotmail.com.https://orcid.org/0000-0002-8789-737X

$5 \quad \mathrm{PhD}$. by London School of Economics. Professor at London School of Economics. Postal Address: LSE, Houghton Street, London WC2A 2AE, U.K. Contact: 1.garcia@1se.ac.uk. https://orcid.org/0000-0001-9166-0263

$6 \quad \mathrm{PhD}$. by Catholic University of Lovania. Professor at University of the Basque Country. Postal Address: Avenida Tolosa 70,20018 San Sebastián. Contact: Dario.paez@ehu.eus. https://orcid.org/0000-0002-8459-6037

7 National University of the Argentine Defense.

$8 \quad \mathrm{PhD}$. by National University of the Argentine Defense. Assistant Researcher at University of Buenos Aires. Contact: fernandamarielsosa@hotmail.com 
is an experimental between-within study of five scenarios by two conditions (Milgram, 1974). Personal and collective obedience of other military, emotional reactions and values of Schwartz (2012) were measured. Showing enhancement of self-bias it is reported that the pairs would be more likely to shoot than one would. Replicating Milgrams's results, obedience is greater when the order is given directly by an authority, and lower when there is conflict between authorities and peers rebel. Confirming that identification with humanity and not just with the in-group may prompt respondents to reject an anti-normative order, values of transcendence of the self are associated with less obedience and congruent emotional reactions. Self-perceived transformational leadership was associated with positive emotions towards peer that disobey to fire. However a transformational style perceived in the superior was associated to positive emotions by respect to soldier who open fire, adding information on the potential dark side of this leadership style. The relevance of personal values, leadership style and affectivity in military context is discussed.

Keywords: leadership style; military psychology; obedience to authority; values; war crime.

\section{Obediencia a la autoridad, respuestas cognitivas y afectivas y estilo de liderazgo en relación a una orden no normativa: el experimento de Milgram}

Se analiza la influencia del contexto en las reacciones conductuales y emocionales ante una situación de crimen de guerra en cadetes militares $(\mathrm{N}=315)$. El estudio se basa en la experiencia de Milgram y en la tragedia de My Lai. Examina la obediencia personal y de los compańeros ante una orden antinormativa (preguntando a los participantes si obedecerían una orden de disparar a civiles desarmados) en cinco vińetas o escenarios que reproducen las condiciones de Milgram y el escenario de MyLai. Se trata de un estudio experimental entre dos escenarios por dos condiciones (Milgram, 1974). Se midió la obediencia personal y colectiva de otros militares, las reacciones emocionales y los valores de Schwartz (2012). Mostrando el aumento de la auto-prejuicio se informa de que los pares serían más propensos a disparar que uno. Replicando los resultados de Milgram, la obediencia es mayor cuando la orden es dada directamente por una autoridad, y menor cuando hay conflicto entre autoridades y compañeros rebeldes. Confirmando que la identificación con la humanidad y no solo con el grupo interno puede impulsar a los encuestados a rechazar una orden antinormativa, los valores de trascendencia del yo se asocian con menos obediencia y reacciones emocionales congruentes. El liderazgo transformacional autopercibido se asoció con emociones positivas hacia los compañeros que desobedecen al fuego. Sin embargo un estilo transformacional percibido en el superior se asoció a emociones positivas por respeto al soldado que abre fuego, añadiendo información sobre el potencial lado oscuro de este estilo de liderazgo. Se discute la relevancia de los valores personales, el estilo de liderazgo y la afectividad en el contexto militar.

Palabras clave: estilo de liderazgo; psicología militar; obediencia a la autoridad; valores; crimen de guerra.

Obediência à autoridade, respostas cognitivas e afectivas e estilo de liderança em relaçáo a um comando náo-normativo: a experiência de Milgram.

A influência do contexto nas reacçôes comportamentais e emocionais a uma situação de crime de guerra em cadetes militares $(\mathrm{N}=315)$ é analisada. O estudo é baseado na experiência de Milgram e na tragédia de My Lai. Examina a obediência pessoal e de pares a uma ordem anti-normativa (perguntando aos participantes se obedeceriam a uma ordem para 
Obedience to authority, cognitive and affective responses and leadership style / Da Costa et al.

disparar contra civis desarmados) em cinco vinhetas ou cenários que reproduzem as condiçóes de Milgram e o cenário MyLai. Este é um estudo experimental entre dois cenários para duas condiçôes (Milgram, 1974). Foram medidas a obediência pessoal e colectiva de outros militares, reacçōes emocionais, e os valores de Schwartz (2012). Mostrando um aumento do auto-julgamento, é relatado que os pares teriam mais probabilidades de disparar do que um. Replicando os resultados de Milgram, a obediência é maior quando a ordem é dada directamente por uma autoridade, e menor quando há conflito entre autoridades e pares desordeiros. Confirmando que a identificação com a humanidade e náo apenas com o grupo ing pode levar os inquiridos a rejeitar uma ordem anti-normativa, os valores da transcendência do eu estáo associados a uma menor obediência e a reacçóes emocionais congruentes. A liderança transformadora auto-percebida foi associada a emoçóes positivas para com os seus pares desobedientes ao fogo. Contudo, um estilo transformacional superior foi associado a emoçóes positivas por respeito ao soldado que abre fogo, acrescentando informação sobre o potencial lado negro deste estilo de liderança. A relevância dos valores pessoais, estilo de liderança e afectividade no contexto militar é discutida.

Palavras-chave: estilo de liderança; psicologia militar; obediência à autoridade; valores; crime de guerra.

\section{Obéissance à l'autorité, réponses cognitives et affectives et style de leadership en rela-} tion avec un commandement non normatif : l'expérience de Milgram.

L'influence du contexte sur les réactions comportementales et émotionnelles à une situation de crime de guerre chez des cadets militaires $(\mathrm{N}=315)$ est analysée. L'étude est basée sur l'expérience de Milgram et la tragédie de My Lai. Elle examine l'obéissance personnelle et celle des pairs à un ordre anti-normatif (en demandant aux participants s'ils obéiraient à un ordre de tirer sur des civils non armés) dans cinq vignettes ou scénarios qui reproduisent les conditions de Milgram et le scénario MyLai. Il s'agit d'une étude expérimentale entre deux scénarios pour deux conditions (Milgram, 1974). L'obéissance personnelle et collective des autres militaires, les réactions émotionnelles et les valeurs de Schwartz (2012) ont été mesurées. En montrant un jugement de soi accru, il est rapporté que les pairs seraient plus susceptibles de tirer qu'un seul. En reproduisant les résultats de Milgram, l'obéissance est plus élevée lorsque l'ordre est donné directement par une autorité, et plus faible lorsqu'il y a conflit entre les autorités et les pairs indisciplinés. Confirmant que l'identification à l'humanité et pas seulement au groupe interne peut pousser les répondants à rejeter un ordre anti-normatif, les valeurs de transcendance du soi sont associées à une moindre obéissance et à des réactions émotionnelles congruentes. Le leadership transformationnel auto-perçu était associé à des émotions positives envers les pairs désobéissants au feu. Cependant, un style transformationnel perçu comme supérieur était associé à des émotions positives par respect pour le soldat qui ouvre le feu, ce qui ajoute des informations sur le côté sombre potentiel de ce style de leadership. La pertinence des valeurs personnelles, du style de leadership et de l'affectivité dans le contexte militaire est discutée.

Mots clés : style de leadership ; psychologie militaire ; obéissance à l'autorité ; valeurs ; crime de guerre. 
This study examines the behavioral and emotional responses to an extreme situation of strong affective and moral load. The dilemma raised is between following the rule of obedience to the authority of the ingroup and shooting at unarmed civilians or respecting the norms of international law of armed conflicts by disobeying the order. Studies on emotions indicate that situations in which rules are broken and injustices are committed result in irritation, anger and indignation. Situations in which moral norms are violated generate negative moral emotions such as shame and guilt. Events involving loss mainly provoke sadness. Keeping up moral standards, on the other hand, generates pride, and obtaining adequate results generates happiness (Ekman, 2017; Palmero \& Martínez, 2008)

\section{Authority and obedience to non normative orders}

The power of any authority figure (Rielly, 2010) is based on the perception of his or her position within a social structure. In other words, an authority figure has the knowledge (real or assumed) to define both the problem and the most appropriate response, thus defining reality itself. Their power is also based on their ideological legitimacy, e.g. on the fact that they are perceived as someone with the right to give orders and prescribe a type of behaviour, as well as someone whom others feel obliged to obey. In socialization, emphasis is placed on the rule of obedience to authority, which involves the realization that one is subordinate to authority or is a mere agent who is in no way responsible for the content of the orders one obeys. This agentic state (as Milgram calls it) is faithfully represented in a very common response given by those who have committed crimes against humanity: "I was just following orders" (Blass, 1999; Milgram 1974). Surveys carried out during the 1980s in USA found that, when placed in a situation 
similar to that of My Lai's (Reilly, 2010), 51\% of respondents stated they would have obeyed orders given by their commanding officer and would have opened fire on unarmed civilians.. They also estimated that $67 \%$ of people in general would do the same. In a similar study carried out at the beginning of the 21st century in Spain (the Basque Country), none of the respondents said they would have opened fire. Nevertheless, they estimated that $31 \%$ of other people would do so (Páez \& Campos, 2004).

In both cases, interviewees thought that other people were more likely to have opened fire than themselves for two reasons. First the primus inter pares effect (e.g. the belief that one is better than average and engages in more normative and less anti-normative actions than most other people) is associated with self-enhancement or self-glorification. It is a positivistic bias that reinforces a benevolent vision of the self and fosters wellbeing (Hoorens, 1993; Sedikides et al., 2003). Second, people tend to project beliefs and attitudes onto others. This is called false consensus bias, because it refers to the fact that a certain attitude or behavior is believed to be more shared and normalized than it actually is by those who endorse the attitude or perform the behavior compared to people that behave differently and do not share the attitude. In this vein, people's own attitudes and behaviors are strongly correlated with their estimates of how others behave and what attitudes others endorse. Usually, the primus inter pares effect is strongly associated with false consensus bias (Dawes \& Mulford, 1996).

\section{The Milgram experiment}

This study analyzes the influence of different contexts/scenarios on expected behavioral and emotional reactions to a war crime situation. It also analyzes the role of personal values,. The destructive obedience demonstrated in Milgram's experimental study and the differences in obedience level provoked by status variations, proximity and disagreement expressed by peers and authorities are similar in 
nature to phenomena occurring in the real world (e.g., obedience of German soldiers during World War II and of US soldiers during the My Lai massacre in Vietnam) (Elms, 2009; Milgram, 1974). Along with identification with authority and non-identification with victims, the ideology legitimizing obedience (scientific value of the experiment) has been proposed as an argument for the obedience gradient.

In this study, the experiment was conducted with students of a military academy, socialized in obedience to authority as well as international laws on wartime behavior, according to which opening fire on unarmed civilians is an unlawful act. The study sought to analyze respondents' reactions to this dilemma. The Red Cross carried out studies in different countries, some of which were at war and some of which were not. These studies show that combatants are aware of the dictates of international law in relation to wartime behavior and agree with them. However, this knowledge is not directly applied to specific circumstances (e.g., it is more acceptable to punish civilians who collaborate with the enemy) (Muñoz-Rojas \& Fressard, 2004).

\section{Contextual influences and values as desirable goals in life}

Although it is expected that the majority of interviewees would say that say they would not open fire, the response profile is expected to reflect the influence of situational factors. These factors are described below. Some authors propose a "revisionist" view of Milgram's study, in which inducing identification with science versus non-identification with victims groups explains the different levels of obedience observed (Haslam \& Reicher, 2012). If this were the case, stable in-group and out-group identification would be associated with the same level of obedience. However, we expect that, despite the existence of a collective identity and a stable out-group (army versus civilians), contextual differences would affect people's reactions, because context provides a framework for decisions (Kanheman, 2012). Nevertheless, identification with humanity and not only with the in-group may prompt 
respondents to reject an anti-normative order. Self-transcendence values (universalism) represent the importance attached to goals such as living in a peaceful world and ensuring equality and social justice for all. In this sense people who share these values are expected to be more likely to disobey an anti-normative order. In contrast, given that the values of conservatism include an appreciation for security, tradition, respect and, above all, conformity, it is expected that those who share these values will be more likely to obey. It is important to remember that these values also emphasize obedience to rules. Finally, the values of openness to change include independence and autonomy. Therefore, it is reasonable to expect that those who share these values are less likely to obey an anti-normative order (Schwartz, 2007, 2012).

\section{Obedience to authority and leadership}

The socialization leadership style, along with creativity and innovation in response to unlawful orders probably influence the responses given. One of the dimensions of transformational leadership is intellectual stimulation which increases the creativity of the members of the led group (Mumford et al., 2002b). A transformational leader is one who is able to lead others towards a goal which is perceived as shared, and to foster commitment among work groups and the organization in general. Transactional leadership, on the other hand, works on the basis of the exchange of objective and subjective rewards with subordinates (Hermosilla et al., 2016; Molero \& Morales, 2011b). The types of behaviours associated with transformational leadership coincide with some factors that favor creativity and innovation found in meta-analyses. These types of behaviors include the transmission of clear goals, rules and vision, support for innovation, reward or acknowledgment, autonomy and a challenging work environment (da Costa et al., 2014; da Costa et al., 2015). A positive and transformational view held by both the participant or perceived in his or her immediate superior and organizational leadership is expected to correlate significantly with the 
rejection of anti-normative orders, as well as with affective responses (e.g. higher positive emotions and low negative emotions towards their comrades that disobey the order) and a higher degree of originality and effectiveness in response to the orders given. The idea is that transformational and positive leadership style enhances normative outcomes.

Aims and hypotheses. One of the aims of this study was to analyze the influence of different contexts/scenarios on expected behavioral and emotional reactions to a war crime situation. Another was to analyze emotional reactions to the dilemma of opening fire/not opening fire on unarmed civilians (e.g. the situation that arose in the My Lai episode in Vietnam). The third aim was to explore the role of personal values, leadership and social representations of creativity and innovation. We hypothesized that personal and perceived obedience would be greater when the person in question recognizes the proximity and legitimacy of the order giver, and would be lower when authorities are divided, following the gradient found in Milgram's classic experiment (H1). The experimental conditions were expected to influence negative emotions and punishment-based actions versus positive emotions and reward-based actions. In other words, we hypothesized that statistically significant differences in affect and emotions would be found, depending on the experimental condition. Specifically, low negative emotions and high positive emotions were expected in the disobedience condition, while the opposite was expected in the obedience condition (H1.1). Self-enhancement and false consensus biases were also expected to be found. Differences were expected in these two variables according to the experimental conditions, with self-enhancement being higher in the less constrictive context (e.g. peer rebellion and conflicting officers) and false consensus stronger in the more constrictive scenario in which expected obedience would be higher (e.g. direct order from an officer (H1.2). We also expected that participants with higher levels of self-transcendence and openness to change values would report lower levels of obedience, and those with higher levels of conservatism, who emphasize conformity, would report higher levels of obedience (H2). Those scoring higher on self-transcendence and open- 
ness to change were expected to respond with more positive emotions to the soldiers who rebelled and to the helicopter team that prevented the war crime (H2.1). In contrast, those scoring higher on the values of conservation and lower on self-transcendence and openness were expected to respond with more negative emotions toward the soldiers who disobeyed and with more positive emotion toward those who obeyed (H2.2). Those with a more positive view of leadership styles (cited above) were expected to respond with greater positive affectivity to the soldiers who rebelled and the helicopter team that prevented the war crime, and to respond with greater negative affectivity to the soldiers who obeyed the order (H3).

\section{Method}

\section{Participants}

The sample consists of 315 cadets from an institute of military superior training in Latin America. At the time of the survey, they reported being in their 3rd and 4th year and belonging to different divisions (31\% infantry, 13\% artillery, 12\% communications and engineering in equal percentage and $11 \%$ to cavalry) and specialties $(13 \%$ to arsenals and $7 \%$ to Intendance). All the participants exercise leadership over other military cadets. $88 \%$ of the sample reported being male and $12 \%$ female, between 20 and 29 years old $(M=23.52, S D=2.39)$. Informed consent and principle of confidentiality were requested.

\section{Procedure}

Participants carried out three individual and group tasks in their academies over the course of a week. These tasks were coordinated at all times by a supervisor, the researchers responsible for the study and a team of support researchers. Participants completed a task and instrument booklet containing the designated variables in a single session lasting approximately 1 and half hours. The experimental design consisted of a 5-level between-subject factor, a two level between subject 
and a two-level whitin subject factor. The five scenarios to be explained below reproduced some conditions of the Milgram experiment (1974) and constituted the first between or inter-factor. The second interfactor consisted of two orders of peer evaluation. In the first, shooters were evaluated first followed by non-shooters (shoot / not shoot) and in the second, the other way around (no shoot / shoot). This was intended to balance the possible anchoring on the first stimulus (Crano et al., 2015). Finally, the intra or repeated factor consisted of all subjects evaluating two stimuli: pairs that fired or obeyed the order and those that did not fire or disobeyed the order.

\section{Scenarios/experimental situation}

Vignette (I). People received this information: Imagine a war situation. A platoon, of which you are a part, enters a village or town after a battle. There are unarmed women, children and elderly people. They faced different scenarios: Baseline condition (CLB): The platoon lieutenant ordered to shoot these unarmed people (Scenario 1). Condition command at distance authority (CODA): The lieutenant of the platoon orders by radio - at a distance since he is not present there - shoot on these unarmed people (Scenario 2). Condition authority minor status (CAME): The platoon sergeant orders - since the lieutenant is not present there - shoot on these unarmed people (Scenario 3). Peer rebellion condition (CRP): An officer - the platoon lieutenant - present there orders to shoot at these unarmed people. Several soldiers say that they should not shoot at unarmed people and refuse to fire (Scenario 4). Condition split between high status people (CDEA): One of the two platoon officers present orders to shoot at these unarmed people while the other says that there is no need to shoot at unarmed people and orders not to fire (Scenario 5). When presented with the scenarios, people had to make a series of decisions and answer some questions.

Instructions: Imagine you are a member/lower-ranking commander of the squad and answer the following questions: would you obey the orders from....? The vast majority $(81.5 \%)$ said they would not shoot, $11 \%$ said they did not know what they would do and $7 \%$ 
said they would obey the order to open fire. The options [yes (2), I don't know (0), no (1)] were re-codified. Given that the "I don't know" response is a socially acceptable way of saying you would perhaps open fire, the variables were unified $(1=1 ; 2=0+2)$. Respondents who said they would not shoot were asked to briefly explain why not. They were also asked to state what percentage of their military comrades they thought would obey, be undecided or would disobey (on a scale of 1 to 100), how likely they themselves would be to shoot on a scale of $1=$ very unlikely to 10 =very likely, and how likely they believe the average soldier would be to shoot (on the same scale). Finally, they were asked to what extent they believed that opening fire on unarmed civilians is a war crime for which perpetrators should be tried and punished (on a scale of $1=$ not at all to $10=$ very much).

These scenarios constitute a five-level intersubject experimental factor. Next, personal affective reaction and the emotional climate were examined. To do this, they were asked: describe what you would feel as a soldier (personal emotions) and what you think your comrades would feel in this situation. Then they had to answer a scale of emotionality.

DES scale (adapted by Izard and based on his theory of positive emotions, Fredrickson (2013). The scale measures affectivity and comprises 20 items [adjectives that describe each emotion at different intensity levels] and two dimensions: positive (10 adjectives, $\alpha=.86$ ) and negative emotionality (10 adjectives, $\alpha=.95$ ). A) What emotions would you feel if your comrades refused to open fire and B) What emotions would you feel if your comrades opened fire Respondents answer on a 5 -point Likert-type scale: $0=$ not at all to $4=$ very much. At the end, they answered other related questions.

Vignette (II). People received this information: A soldier refuses to shoot and informs the members of a helicopter of the situation that lands in the zone. This soldier and the members of the helicopter prevent the execution of the order threatening to use the machine gun of the apparatus if necessary and announce that they will report what happened requiring a council of war. Participants were asked: A.- What do you think you would do? How would you react in this situation? and 
B.- What do you think your comrades would do/how would they react in this situation? (The soldier refuses to open fire and, alongside the members of the helicopter team, prevents the order from being carried out). Next, they had to answer the emotionality scale

Transformational and transactional leadership scale (CELID de Castro Solano et al., 2004). This is a questionnaire of leadership styles, based on the theory of Bass (1985) (Castro Solano \& Benatuil, 2007). It comprises 34 items belonging to three dimensions: transformational leadership [charisma or idealized influence, inspiration, intellectual stimulation and individualized consideration], transactional leadership [contingent reward, management by exception] and laissez faire [absence of any kind of transaction, the leader avoids taking decisions, has no responsibility and does not use his authority]. It is answered on a Likert scale ( 1 = totally disagree to 5 = totally agree). In this study, people were asked to indicate the degree of agreement regarding their own leadership style ( $\alpha=.95$ transformational, $\alpha=.74$ transactional and $\alpha=.77$ laissez faire) and that of their superior (not shown) in this studio)

PVQ-21 (Schwartz, 2001). The Portrait values questionnaire (Spanish version by Castro Solano \& Nader,2006). For the purposes of this study, the scale used was that comprising the 21 items contained in the motivational value dimensions: openness to change [self-direction (creativity, freedom), stimulation (exciting life) and hedonism (pleasure)], self-transcendence [universalism (social justice, equality), benevolence], self-enhancement [achievement (success, ambition)] and conservation [conformity (obedience), security (social order), tradition (humility, devotion)]. For each item, participants are asked "How much like you is this person?" and respond on a Likert-type scale (6 = very much like me to $1=$ not like me at all). The reliability value of the scale in this study was very satisfactory $(\alpha=.80)$.

\section{Data analysis}

Contingency tables and Chi square and ANOVAs using the factor order and five scenarios' factors were carried on reported behavioral 
and emotional reactions, as well as evaluations. A weighted contrast was used to examine in a more focused manner hypothesis (weight were assigned to the five scenarios according to Milgram studies: the higher value for the condition with higher expected obedience (CBL) and the lower for the condition with the lower expectations). ANOVAs using the previous independent variables, and as dependent variable the difference between self-likelihood and peer's likelihood of obey the order and shoot the civilians, was carried out to examine self-enhancement hypothesis. Correlations between self-likelihood and peers-likelihood of obey orders were carried by the five scenarios condition and correlations comparisons were carried out to examine the false consensus hypothesis.

\section{Results}

Table 1 describes the descriptive percentages of personal obedience and other obedience in this study and in another study carried out with a sample of civilians from a similar cultural background as a reference - a Spanish civilian sample (Páez and Campos, 2004).

\section{Table 1}

Obedience to order in this study and in a Spain study (Páez \& Campos, 2004). ¿Do you obey the order and shoot disarmed civilians?

\begin{tabular}{lccc}
\hline & Obey and shoot & Don't know & $\begin{array}{c}\text { Disobey and not } \\
\text { shoot }\end{array}$ \\
\hline $\begin{array}{l}\text { I - Civilians } \\
\text { Spain personal }\end{array}$ & $0 \%$ & $35 \%$ & $65 \%$ \\
$\begin{array}{l}\text { Others civilian } \\
\text { sample Spain }\end{array}$ & $31 \%$ & $31 \%$ & $38 \%$ \\
$\begin{array}{l}\text { I - Cadets } \\
\text { Argentina personal }\end{array}$ & $8 \%$ & $11 \%$ & $81 \%$ \\
Others cadets & $21 \%$ & $25 \%$ & $55 \%$ \\
\hline
\end{tabular}

Military cadets report higher personal but no peer disobedience that a Spanish civilian sample. 


\section{Effects of experimental conditions on behavioural expected reactions}

Descriptive percentages of personal and other obedience in this study and actual behavioral obedience in Milgram's experiment is described in Table 2. Results for expected behavioral obedience were examined with a contingency table. Because of the low level of obedience responses, the percentage of people who said they would obey and were undecided were unified in a category and contrasted with the not obey response (see Table 1, second column for percentages), $(4)=8.19, p=.0425, \rho=097$, $p=.044$. Personal obedience of the order to open fire was higher in the baseline situation and when the order was given by the sergeant - this last result differs from Milgram behavioural profile. Obedience was also lower when the peers rebelled and the officers were in conflict (Table 2). However, the percentage of respondents that said they thought would open fire or were undecided reflects the gradient of that experiment.

\section{Table2}

Experimental conditions, observed and expected or reported obedience

\begin{tabular}{lccc}
\hline \multicolumn{1}{c}{ Condition $\odot^{1}$} & $\begin{array}{c}\text { Milgram } \\
(1974)\end{array}$ & $\begin{array}{c}\text { Personal } \\
\text { obedience }^{2}\end{array}$ & $\begin{array}{c}\text { Others expected } \\
\text { Obedience }^{3} \\
M(S D)\end{array}$ \\
\hline Baseline & $65 \%$ & $21 \%$ & $27.73(20.12)$ \\
Authority distance & $21 \%$ & $19 \%$ & $20.69(23.42)$ \\
Minor status & $20 \%$ & $29 \%$ & $20.74(24.64)$ \\
Peers rebellion & $10 \%$ & $13 \%$ & $18.90(24.02)$ \\
Division authority & $10 \%$ & $11 \%$ & $15.21(21.75)$ \\
\hline
\end{tabular}

Nota. ${ }^{1}$ Conditions vignettes or scripts were codified attributing the following weights, following Milgram (1974): 1=5;2=4;3=3; $=2 ; 5=1 .{ }^{2}$ Do you obey the order? Percentage yes plus undecided ${ }^{3}$ Percentage of members of the army that you expected will obey the order.

Nevertheless, the percentage of comrades that respondents said they thought would open fire reflects the gradient of that experiment. 
The results for personal obedience were examined with an ANOVA and focused contrast. The conditions were used as the independent variables and five variables, percentage of peers expected to obey, percentage of undecided and percentage that would not obey, personal and average army member of opening fire on unarmed civilian, were used as dependent variables (see Table 2 last column and figures 1 to 3). Order effect and interaction effects were not significant. The linear effects for the five scenarios factor were significant for percentage of peers or army members that obey $[F(1)=6.7, p=.01]$, percentage of peers disobey $[F(1)=5.66, p=.018]$ and marginally significant for likelihood of obedience of others, $F(1)=3.55, p=.061$. The relationship is linear for both obedience and disobedience. A contrast test assigned each condition a weight according to the gradient of Milgram's original experiment (1974) was carried out. This was significant for the percentage of respondents who said they would obey,$- r=.15$, $p<.003$ (Figure 1); the percentage of those who said they would not obey $r=-.14, p<.008$ (Figure 2) and the estimated likelihood that the average soldier would open fire $r=.11, p<.02$ (Figure 3).

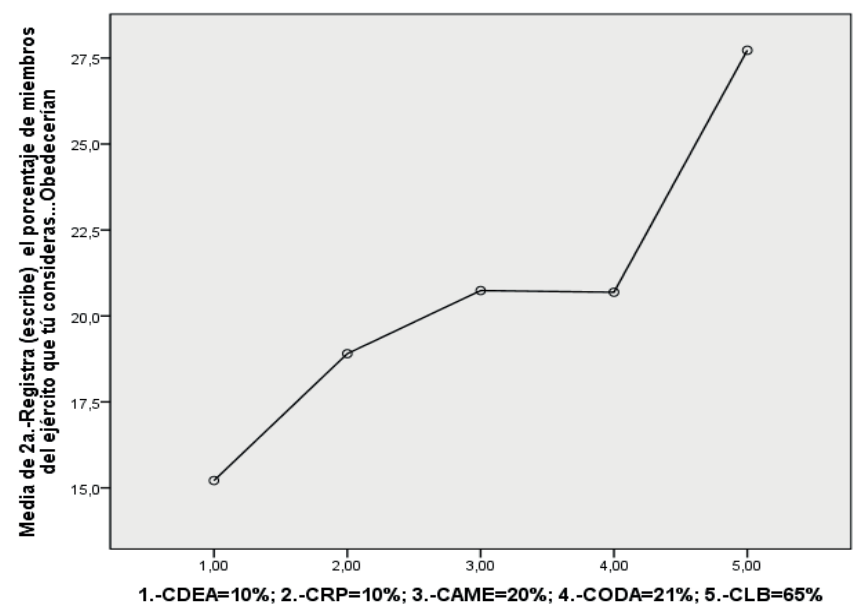

Figure 1. Percentage of army members that obey the order. See means by condition in table 2. 


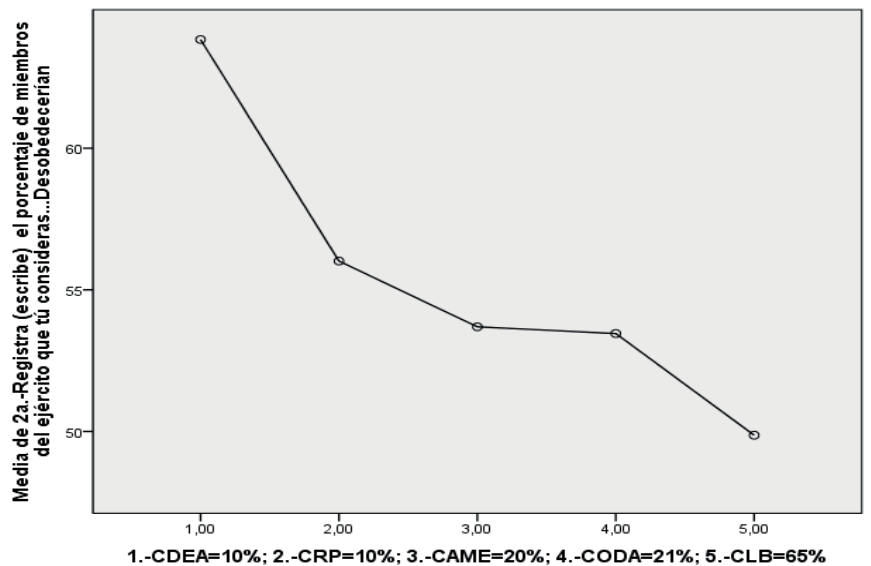

Figure 2. Percentage of army members that disobey the order. Means by condition, $M=63.84$ (1), $M=56.02$ (2), $M=53.69$ (3), $M=53.46$ (4), $M=49.87$ (5)

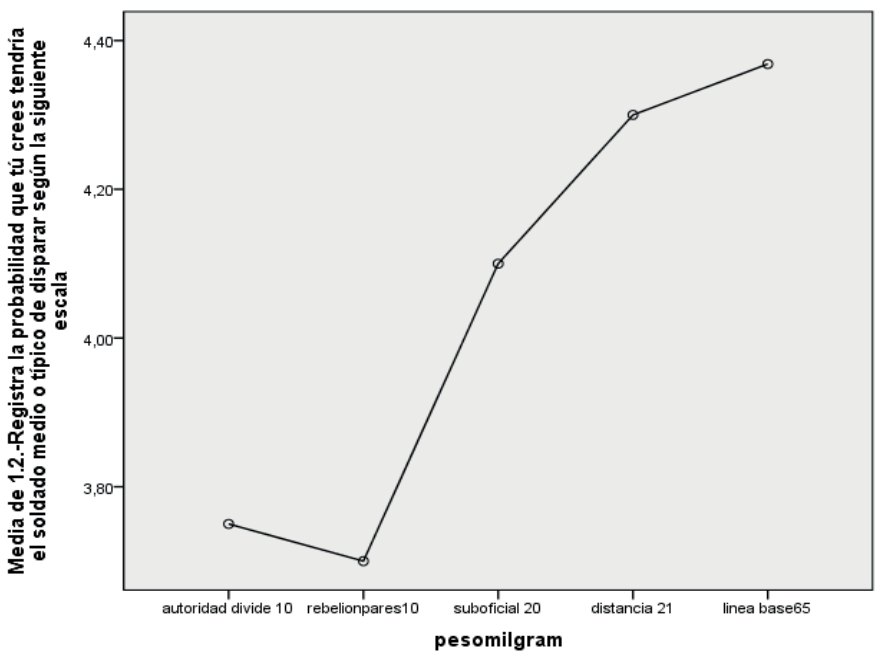

Figure 3. Likelihood that average of army members obey the order. Means by condition, $M=3.75(1), M=3.7$ (2), $M=4.1$ (3), $M=4.3$ (4), $M=4.36(5)$ 


\section{Effects of experimental conditions on emotional reactions and evaluation of peers that obey and disobey orders}

The results of emotional reactions and evaluations of peers obeying and disobeying the order were examined with an ANOVA. Order effect and interaction effects were not significant. The effects for the five scenario factor were also not significant in relation to emotions. Nevertheless, intra or within subjects' factor was significant. A mean comparison analysis using paired t-tests revealed statistically significant differences for soldiers who opened fire and those who did not, and the helicopter intervention. In general, more positive than negative emotions were felt in relation to those who did not open fire and to the presence of the helicopter team that intervened in order to prevent the massacre. The experimental conditions did not affect the emotional reaction in relation to the helicopter team who prevented the massacre, which was (positively) similar to that reported in relation to soldiers who disobeyed the order. The experimental conditions were not found to affect the evaluation of soldiers who obeyed and disobeyed the order. However, an effect was found for the repeated measures or within subject factor. Soldiers who obeyed and opened fire were negatively evaluated $(M=2.38, S D=1.97)$ and significantly more negatively evaluated than those who decided not to open fire $(M=$ $8.57, S D=2.22), t_{(302)}=28.37, p<.000$. These assessments correlated negatively with each other $r=-.62, p<.000$. Concluding, ANOVA analysis showed that the variables related to behaviour were partially influenced by the experimental manipulation. However this did not happen with the emotions (both positive and negative). It also did not happen with evaluations in relation to the five scenarios and the order the conditions. A significant effect was found for the comparison of peers that obey and disobey the order. 


\section{Differences by condition in self-enhancement and correlations between self and others likelihood of shooting}

The ANOVA comparing the difference between the likelihood of the average soldier and the personal likelihood of shooting was not found to be significantly influenced by the different experimental conditions. He main effects of the five-scenario factor and the order factor or interaction were not significant. To examine hypothesis 1.2 , regarding the presence of and differences in responses due to the self-glorification bias according to the different conditions, a mean comparison analysis and paired t-test were carried out. The results indicate that respondents saw themselves as being less likely than the average soldier to shoot $(M$ $=2.74, S D=2.36$ versus $M=4.05, S D=2.49)$ and that the individual likelihood of shooting was projected onto the average soldier $(r=.59$, $p<.000)$. Correlations between the average soldier's likelihood and personal likelihood of shooting were performed separately according to the five scenario conditions. Comparison of the independent correlations found no significant differences between conditions.

\section{Correlation of values with expected behavioural reactions, evaluations and reactions towards peers obey and disobey the order}

The responses to the scenario were correlated with the personal variables in order to test the second hypothesis. Self-transcendence values (specifically benevolence) $[r=-.12, p<.009 ; r=-.13, p<.01]$ was found to be significantly negatively associated with the decision to shoot. Consistently with that postulated, the personal likelihood of shooting correlated negatively with the values of self-transcendence (universalism and benevolence) $\left[r_{(301)}=-.12, p<.04\right.$ (universalism). This likelihood was negatively associated with openness to change, specifically stimulation $\left(r_{(301)}=-.13, p<.01\right)$. Positive assessments of the soldiers who refused to shoot were associated with the values of self-transcendence $(r=.14, p<.009$ and negatively related $r=-.18$, $p<.001$ for those who decided to shoot) and openness $(r=.12$, $p$ $<.01)$. Assessments of those who opened fire were negatively associ- 
ated with the values of self-transcendence $(r=-.18, p<.001)$ and the conservative values of tradition and security (both $r=-.10, p<.03$ ). No associations were found with any of the other values. The values of self-transcendence correlated with some reactions like not punishing those who opened fire $(r=-.10, p<.04)$, and with providing them with training in human rights $(r=.16, p<.005)$. They were also associated with dismissing those who opened fire from the corps $(r=.10, p<.04)$, providing them with training in human rights $(r=.13, p<.01)$ and not decorating them $(r=.13, p<.02)$. Openness to change was associated with providing human rights training to those who refused to open fire $(r=.11, p<.03)$ and with the decision not to decorate those who did $(r=-.13, p<.02)$. For its part, conservatism was associated with decorating those who did not open fire $(r=.12, p<.03)$ and achievement was linked to punishing those same people $(r=.11, p<.0)$.

\section{Correlation of leadership style with expected behavioural reactions, evaluations and reactions towards peers obey and disobey the order}

As regards the relationship between leadership style and reactions, associations were found with affective but no with behavior reactions. The higher the level of self-perceived transformational and transactional leadership, the more positive the emotions in response to the helicopter $(r=.15, p<.007$ y $r=.11, p<.03$ respectively). The higher the level of self-perceived transactional leadership the more positive emotions, both personal and attributed to others, in response to the arrival of the helicopter team $(r=.11, p<.03$ and $r=.14, p<.01)$. The laissez-faire or non-leadership style, both self and hetero-perceived, was found to have an $r=-.12, p<.03$ in relation to the positive heteroassessed reaction to the presence of the helicopter team. A negative association was found between this style and positive emotions, both personal $(r=-.11, p<.03)$ and attributed to others $(r=-.10, p<.04)$, in front of peers that do not shoot. 
In contrast, the results reveal that the higher the level of transformational $(r=.14, p<.01)$ and transactional $(r=.16, p<.005)$ leadership of the superior officer, the more positive emotions are felt in relation to the soldiers who opened fire. A more positive view of the immediate superior is associated with positive emotional reactions to soldiers that obey the order. Transactional leadership perceived in one's superior officer is also associated with a more positive assessment of those who opened fire $(r=.12, p<.02)$, more positive emotions towards the helicopter team $(r=.15, p<.007$ personal and $r=.12, p<$ .03 hetero-perceived).

\section{Discussion and conclusion}

First, the study shows that the vast majority of participants report that they would disobey the order to open fire on unarmed civilians. Second, participants believe that that the vast majority of participants report that they would disobey the order to open fire on unarmed civilians. Also, participants believe that only a small percentage of their comrades would shoot, while the majority would refuse to open fire. Third, the reported likelihood of shooting (both personal and that of the average soldier) is low. These military cadets believe, more intensely than a sample of Spanish civilians (Páez \& Campos, 2004), that they would not open fire under these circumstances. They also believe that a percentage of their comrades would obey an order that involved committing a war crime. Fourth, this decision was the worst rated, confirming its anti-normative nature. Respondents felt more negative and less positive emotions in relation to soldiers who would shoot than about those who would not. These results suggest that people share a means of socialization and a set of rules regarding respect for human rights in armed conflicts. They also suggest that a minority would prioritize obedience to authority, particularly if it is legitimate and proximal.

The first hypothesis was partly confirmed, since contextual conditions were found to influence how participants thought their comrades 
would respond to an antinormative order. Conditions influenced the expected behavioral responses (despite the succinct description of the scenario presented), it was found that the closer the legitimate authority, the more likely participants were to think that comrades would open fire, and the higher the percentage of people in general who thought they would do the same. However, when officers were divided or when fellow officers rebelled, the estimated disobedience was greater, rising as high as $90 \%$. The obedience level was higher when the officer was nearby, although in this study, the highest level was obtained when the order was given by the lower-ranking officer or sergeant. Probably familiarity and closeness of platoon members with their sub officer could explain this relatively higher obedience to a non-normative order. According to the results, the factors which reinforce obedience in Milgram's experiment are manifested in response to anti-normative actions such as those analyzed in this study. The division of authority and peer rebellion serve to weaken the social pressure to obey. This occurs even when orders contravene the ethical wartime regulations in which participants in this study are trained.

In contrast to the idea that the induction of identification with the institution giving the order, versus identification with the victim of the shock, explains the different levels of obedience observed, this study found that differences in context affect the estimated reactions of others. Even though both the institution and the victims remained the same, and thus the level of identification did not vary (Haslam \& Reicher, 2012). Context likely frames decisions and affects the estimated likelihood of certain responses (Kahneman, 2012). Nevertheless, this only occurs here in relation to estimates of other people's responses, whereas respondents' personal reactions, which are probably based on more central values and slower (rather than fast or heuristic) reasoning, remain unaffected.

Although variables related to expected peer behavior were influenced by the experimental manipulation, this was not the case in relation to emotions and assessments of these comrades. In general, more positive than negative emotions were felt in relation to those 
who did not open fire and to the presence of the helicopter team who intervened in order to prevent the massacre. The opposite, however, was true in relation to the soldiers who did open fire, who received the poorest assessment. This result suggests that the change in context affects participants' judgment (Kanheman, 2012) but is not based on a different affective logic. Furthermore, expected behavior, emotions and assessments were closely correlated which excludes the possibility of some sort of independent parallel modular process. The primus inter pares effect is clearly manifested, since respondents estimated their personal likelihood of opening fire to be muchlower than that of the average soldier (Hoorens, 1993; Sedikides et al., 2003). The socalled false consensus bias (Mullen et al., 1985) was also confirmed, since the personal likelihood of opening fire was strongly associated with that of the average soldier. However, contrary to expectations, the experimental conditions were not found to affect the self-enhancement or glorification bias nor the size of correlation between self and peers expected likelihood of obey in the order and shooting civilians. This correlation was significant and strong. This means that primus inter pares and false consensus biases were manifested with the same intensity in all the different obedience contexts induced by the experiment.

Those who were undecided or who decided to open fire gave better assessments of and reported more positive emotions towards their peers who obeyed the order. They reported fewer positive and more negative emotions in relation to those who did not open fire and the helicopter team who intervened in order to prevent the massacre. The same profile was also found for those reporting a greater personal likelihood of opening fire and a greater estimated likelihood of the average soldier doing the same. In this sense we suggest that people consistently align their assessments and emotions with their behavior: if I decide not to open fire and believe that I have a lower personal likelihood of doing so, then I also believe that others would do the same; I also assess positively and have a positive affective response to those who share my decision and assess negatively and have a negative affective response to those who do not. This result can be interpreted 
as a manifestation of cognitive consistency. This is defined as people's preference for consistency (e.g. no contradiction) between their beliefs, knowledge, opinions, attitudes and behavioral intentions. This consistency should also encompass how people see themselves and their past and future conduct (Simon \& Snow, 2004).

Our results confirm that the values of self-transcendence (particularly universalism) are positively associated with the self-perceived likelihood of not shooting, while the hetero-assessed likelihood of the average soldier doing the same is also associated in the same way with this value, as well as with openness to change (specifically stimulation). These values are also associated with the belief that opening fire on unarmed civilians should be judged and punished, as well as with positive assessments of soldiers who refuse to obey the antinormative order. Globally, results confirm that self-transcendence values act as barriers to anti-normative orders. Nevertheless, the expected positive relationship of obedience with conservative values was not observed. The few associations observed revealed a negative relationship between these values and reactions towards peers that shoot. It is possible that valuing tradition and security constitutes an obstacle for a positive attitude towards the order to open fire on unarmed civilians. Conservatism is not associated with obedience, probably due to the anti-normative nature of the order. Concluding, the results partially confirm the idea that the values which foster identification with large social groups and universal justice also help people resist negative orders given by authority figures.

The third hypothesis was also partially confirmed. As expected, selfperceived transformational leadership was positively associated with both positive personal emotions and positive hetero-assessed emotions in relation to the presence of the helicopter team that impedes the massacre. Because transformational leadership emphasizes going beyond expectations, this could feed positive evaluation of heterodox actions, like the helicopter team intervention. However, at odds with our expectations, the perception of a high level of transformational and transactional leadership in one's superior officer was linked to more positive emotions in relation to the soldiers who opened fire, suggesting that a positive view of 
both styles fosters a global positive evaluation of officers and a benevolent attitude towards soldiers who obey orders given by their superior officers. A good example in this case is the argument "(...) if he is a good boss, then the order will probably be obeyed, otherwise it won't. (...)" used by one of the participants. These results show the dark side of a positive view of superior leadership: they can reinforce positive affective reactions to antinormative orders by these authority figures. Our data adds information on the potential negative side of this leadership charismatic style, that could encourage collective narcissism, hubris or exaggerated pride and poor decision-making on the part of leaders and followers (Khoo \& Bursch, 2008; Tourish, 2013; Zhang et al., 2020).

Self-perceived transactional leadership plays an ambivalent role, with significant positive associations being found with negative emotions in the shoot conditions, and with positive self and heteroperceived emotions in relation to the helicopter team. Hetero-assessed transactional leadership was found to have a similar profile to that of transformational leadership. The laissez faire style plays a consistent role in both its versions (self and hetero-assessed), with statistically significant negative associations being observed for positive emotions and statistically significant positive ones being found for negative emotions by respect to the helicopter team and peers that don't shoot.

This study has certain limitations. Firstly, the effect sizes are small, around $=.10$, and explain only $1 \%$ of the variance. However, they are consistent with other effect sizes, such as that of expressive writing or minority influence. It is also important to remember that the median and mean effect size in social psychology is .19 and .21 respectively (Richards et al., 2003) and .16 and .22 in organizational psychology (Bosco et al., 2015). Another limitation is the fact that the study is based on a "mental simulation" and self-reports, and obedience may well be higher in real situations. Indeed, more recent studies have replicated the results reported by Milgram in responses with less serious consequences (Blass, 1999). Finally, it is important to note that the sample group comprised of people being socialized as members of the Armed Forces, and the dilemma used may be relevant to those receiving training regarding international laws on armed conflicts. 


\section{References}

Blass, T. (1999). The Milgram Paradigm After 35 Years: Some Things WeNowKnowAboutObedienceToAuthority.J.Appl.Soc.Psychol. 29(5), 955-978. https://doi.org/10.1111/j.1559-1816.1999. tb00134.x

Bosco, F.A., Aguinis, H., Singh \& Field, J.G. (2015). Correlational Effect Size Benchmarks. J. Appl. Soc. Psychol. 100(2), 431-449. https://doi.org/10.1037/a0038047

Castro Solano, A. \& Nader, M. (2004). Estilos De Liderazgo, Contexto y Cultura Organizacional. Un Estudio Comparativo En Población Civil Y Militar. Bol Psicol. 82, 45-65.

Castro Solano, A. \& Benatuil, D. (2009). Estilo De Liderazgo, Inteligencia y Conocimiento Tácito. An. de Psicol. 23(2), 216-225.

da Costa, S. Paez, D. Sánchez, F., Garaigordobil, M. \& Gondim, S. (2015). Personal Factors of Creativity: A Second Order MetaAnalysis. J. Work. Organ. Psychol. 31(3), 165-173. https://doi. org/10.1016/j.rpto.2015.06.002

da Costa, S., Páez, D., Sánchez, F., Gondim, S. \& Rodriguez, M. (2014).

Factores Favorables a la Innovación en las Organizaciones: Una Integración de Meta-Análisis. Rev. Psicol. Trab. Org. 30(2). 67-74. https://doi.org/10.1016/j.rpto.2014.06.006

Dawes, R. M., \& Mulford, M. (1996). The False Consensus Effect and Overconfidence: Flaws in Judgment or Flaws in How we Study Judgment? Organ. Behav. Hum. Decis. Process. 65(3), 201-211. https://doi.org/10.1006/obhd.1996.0020

Ekman, P. (2017). El Rostro de las Emociones. Barcelona: RBA. Elms, A. (2009). Obedience Lite. Am. Psychol. 64(1), 32-36. https:// doi.org/10.1037/a0014473

Fredrickson, B. L. (2013). Positive Emotions Broaden and Build. In P. G. Devine \& E. A. Plant (Eds.), Adv. Exp. Soc. Psychol. (Vol. 47, pp. 1-53). Burlington, VT: Academic Press 
Haslam, A. S., \& Reicher, S. D. (2012). When Prisoners Take Over The Prison: A Social Psychology Of Resistance. Pers. Soc. Psychol. Rev. 16, 154-179. https://doi.org/10.1177/1088868311419864 Hermosilla, D., Amutio, A., da Costa, S. \& Páez, D. (2016). El liderazgo Transformacional en las Organizaciones: Variables Mediadoras y Consecuencias a Largo Plazo. J. Work. Organ. Psychol. 32(3), 135-143. doi.org/10.1016/j.rpto.2016.06.003

Hoorens, V, (1993). Self-Enhancement and Superiority Biases in Social Comparison. Eur. Rev. Soc. Psychol. 4 (1) 113-39. https://doi. org//10.1080/14792779343000040.1016/j.rpto.2016.06.003

Kahneman, D. (2012). Pensar Rápido, Pensar Despacio [Thinking, Fast and Thinking Slow]. Barcelona: New York: Farrar, Straus and Giroux.

Khoo, H.S. \& Burch, G. (2008). The 'Dark Side' of Leadership Personality and Transformational Leadership: an Exploratory Study. Pers. Individ. Differ. 44(1), 86-97 https://doi. org/10.1016/j.paid.2007.07.018

Milgram, S. (1974). Obedience to Authority. New York: Harper and Row.

Molero, F., \& Morales, J. F. (2011). Liderazgo: Hecho y Ficción. Visiones Actuales. Madrid: Alianza Editorial.

Mullen, B., Atkins, J. L., Champion, D. S., Edwards, C., Hardy, D., Story, J. E., \& Vanderklok, M. (1985). The False Consensus Effect: A Meta-Analysis of 115 Hypothesis Tests. J. Exp. Soc. Psychol. 21(3), 262-283. https://doi.org/10.1016/0022-1031 (85)90020-4

Muñoz-Rojas, D., \& Frésard, J. J. (2004). The Roots of In War: Understanding and Preventing IHL Violations. Int. Rev. Red Cross 86(853), 189-206. https://doi.org/10.1017/ S1560775500180150

Mumford, M. D., Scott, G. M., Gaddis, B., \& Strange, J. M. (2002). Leading Creative People: Orchestrating Expertise and Relationships. Leadersh. Q. 13(6), 705-750. https://doi. org/10.1016/S1048-9843 (02)00158-3 
Páez, D. \& Campos, M. (2004). Cultura e Influencia Social: Conformismo e Innovación. In D. Páez, I. Fernández, S. Ubillos \& E. Zubieta (Eds.), Psicología social, Cultura y Educación (pp. 693-719). Madrid: Pearson Prentice

Palmero, F., \& Martinez, F. (2008). Motivación y Emoción [Motivation and Emotion]. Madrid: McGraw-Hill.

Richard, R. D., Bond, C. F., Jr., \& Stokes-Zoota, J. J. (2003). One Hundred Years of Social Psychology Quantitatively Described. Rev. Gen. Psychol. 7(4), 331-363. https://doi. org/10.1037/1089-2680.7.4.331

Rielly, R. (2010). Military Review, Tomo XC, 1, 74-81.

Schwartz, S. (2012). An Overview of the Schwartz Theory of Basic Values. Online Readings in Psychology and Culture, 2(1). https:// doi.org/10.9707/2307-0919.1116

Schwartz, S.H. (2001). ¿Existen Aspectos Universales en la Estructura y Contenido de los Valores? In M. Ros \& V. Gouveia (Eds.). Psicología Social de los valores humanos (pp. 53-78). Madrid: Biblioteca Nueva.

Sedikides, C., Gaertner, L., \& Toguchi, Y. (2003). Pancultural SelfEnhancement. J. Pers. Soc. Psychol. 84(1), 60-79. https://doi. org/10.1037/0022-3514.84.1.60.

Simon, D., Snow, C. J. \& Read, S. J. (2004). The Redux of Cognitive Consistency Theories: Evidence Judgments by Constraint Satisfaction. J. Pers. Soc. Psychol. 86(6), 814-837. https://doi. org/10.1037/0022-3514.86.6.814.

Tourish, D. (2013). The Dark Side of Transformational Leadership: A Critical Perspective. London: Routledge.

Zhang, X., Liang, L., Tian, G. \& Tian, Y. (2020). Heroes or Villains? The Dark Side of Charismatic Leadership and Unethical Proorganizational Behavior. Int. J. Environ. Res. Public Health, 17, 5546. https://doi.org/10.3390/ijerph17155546 


\section{Ethics Statement}

Ethical review and approval of the studies was required in accordance with the legislation of the participating country and institutional requirements. Informed consent and the principle of confidentiality to participate in this research was provided by those who participated in the study.

Recibido: 2020-08-23

Revisado: 2021-02-28

Aceptado: 2021-03-10 